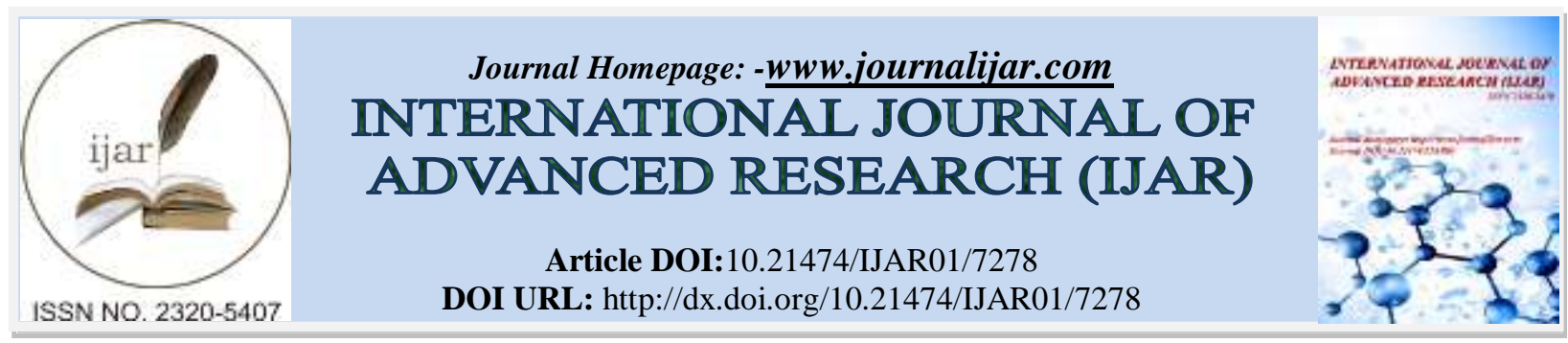

RESEARCH ARTICLE

\title{
VALIDITY TEST OF LEARNING DEVICES IN THE ASSESSMENT OF ECONOMIC LEARNING OUTCOMES SUBJECT USING CONTEXTUAL TEACHING AND LEARNING (CTL) APPROACH.
}

S. Wahyuni and Sumarni.

Economic Education Department STKIP PGRI Sumatera Barat, Padang, West Sumatera, Indonesia.

\section{Manuscript Info}

Manuscript History

Received: 13 April 2018

Final Accepted: 15 May 2018

Published: June 2018

Keywords:-

Validity test, learning device, CTL, 4-D model.

\section{Abstract}

The assessment of Economic Learning Outcomes is a subject that must be followed by every student in the economic education department, STKIP PGRI Sumatera Barat. Students do not understand the concepts in the assessment of economic learning outcomes subject. Students are less able to review and solve the problems contained in textbooks. Students are unable to understand and present the reading report they have done, Consequently, the learning process does not work well and students learning outcomes are low, this is due to the limited learning devices in this subject.The purpose of this study is to produce a learning device on Assessment of Economic Learning Outcomes subject. This type of research is research and development by using 4D model. This model consists of four stages: define,design, develop and the disseminate. In this study is limited to the design stage (validity test) of learning devices. The resulting learning devices are categorized as highly valid. The assessment of economic learning outcomes textbooks with Contextual Teaching and Learning (CTL) approach can be used in learning at the economic education department, STKIP PGRI Sumatera Barat.

Copy Right, IJAR, 2018,. All rights reserved.

\section{Introduction:-}

The economic education department is one of the departments with the largest number of students in STKIP PGRI Sumatera Barat. Each student of economic education department must have special skill standard, that is 1) able to apply the concept, principle, technique, material procedure, knowledge of media, learning method, class management, school management, school administration, high school leadership. 2) able to plan, implement, manage, and evaluate the assessment of student learning outcomes.

Assessment of Learning Outcomes Economics is a subject that must be followed by every student. This subject consists of 3 credits. Assessment of learning outcomes is the overall measurement activity (data collection and information), processing, interpretation and balance to make decisions about the level of learning outcomes achieved by students (Hamalik, 2008). The purpose of this subject so that students have a knowledge base of assessment of student learning result, evaluation of learning outcome result, and able to apply this subject when they have become a teacher. In fact many students do not understand the concepts in this subject. Students are less able to review and solve the problems contained in textbooks. Students are unable to understand and present the reading report they have done, consequently, the learning process of this subject is not going well and the students' learning outcomes are low, this is due to the limited learning devices in this subject. Therefore, it has been developed learning devices 
in the Assessment of Economic Learning Outcome Subject using Contextual Teaching and Learning (CTL) approach. CTL is defined as away to introduce content using a variety of active learningtechniques designed to help students connectwhat they already expected tolearn and to construct new knowledge from the analysisand synthesis of this learning process (Hudson and Whisler, 2017). CTL is a grassroots initiative that has emerged from teachers' efforts to buildcognition research and integrate into one approach a number ofvalidated strategies that are too often employed independently of one another (Glynn and Winter, 2004).

Assessment of Economic Learning Outcomes subject by using CTL approach can link the knowledge that students have during lectures with daily life when they are already teachers. The assessment of Economic Learning Outcome subject with the approach of CTL makes students more active, able to assess the student learning outcomes and find the concept not to remember the concept given by the lecturer. The purpose of this study is to produce a learning device on the Assessment of Economic Learning Outcomes subject, so feasible to be used in the learning process in the economic education department, STKIP PGRI Sumatera Barat.

\section{Material and Methods:-}

This type of research is research and development by using 4-D model. This model consists of four stages: define, design, develop and disseminate. In this study is limited to the design stage (validity test) of learning devices. The data obtained are primary data consisting of validity test by validator the stages of learning device development in Assessment of Economic Learning Outcomes subject are as follows:-

\section{Stage of Define:-}

Stage of the define conducted:-

1. Analysis of the material from the Assessment of Economic Learning Outcomes subject. The material analysis is conducted to determine the suitability between the materials in this subject and the competency standard.

2. Interview with Assessment of Economic Learning Outcomes lecturers.

3. This interview aims to determine the problems that occur during the lecture

4. The distribution of a questionnaire to students

5. The distribution of questionnaires to the students aims to determine the needs of students on the textbook.

\section{Stage of learning device design:-}

1. Design of semester learning plan with CTL approach

2. Designing of lecture unit with CTL approach

3. Design of textbook with CTL approach

\section{Stage of developing (validity test) learning device:-}

The validity test of learning devices in the assessment of economic learning outcomes subject is done by two validators. An instrument of learning device in this research is sheet of learning device validation. The data is then processed so as to obtain the average score (Table 1).

Table 1:-Results of validation in the Assessment of Economic Learning Outcomes subject.

\begin{tabular}{|c|c|c|}
\hline No & The value of validity & Categories \\
\hline 1 & Average $>3.20$ & Very valid \\
\hline 2 & $2.40<$ Average $\leq 3.20$ & Valid \\
\hline 3 & $1.60<$ Average $\leq 2.40$ & Quite valid \\
\hline 4 & $0.80<$ Average $\leq 1.60$ & No valid \\
\hline 5 & $\leq 0.80$ & valid \\
\hline
\end{tabular}

Aspects assessed by the validator, the description of content eligibility, aspect of language eligibility, aspects of presentation eligibility, and aspects of graffiti eligibility. Validation results serve as the basic revision of learning devices in the Assessment of Economic Learning Outcomes subject.

\section{Result and Discussion:-}

Development of learning devices in the Assessment of Economic Learning Outcomes subject with CTL approach is one of the efforts in improving the understanding of student concepts. The results of research that have been obtained, namely: 


\section{Stage of define:-}

The results of the material analysis of Assessment of Economics Learning Outcomes shows that the material sequence of this subject has been systematically arranged. In the syllabus, there is a learning material consisting of 12 chapters with 16 times learning activities. The material in the syllabus is in accordance with the standard of competence that must be achieved by the students. The standard of competence from this subjects are the students able to explain about the Evaluation of Economic Learning Results, students are able to explain the process of evaluation of economic learning Results, students are able to design forms of Assessment of Economic Learning Outcomes at junior and senior high school level, students are able to design the development of methods and development of learning materials on the evaluation of economic learning outcomes in schools.

Interviews with other Assessment of Economic Learning Outcomes lecturers aims to find out the problems encountered during the lecture. The results of the interviews obtained information that the entire material contained in the Assessment of Economic Learning Outcome subject is quite difficult. This is because the students have not understood the concepts of Assessment of Economic Learning Outcome. Students are less able to review and solve the problems contained in textbooks. Students are unable to understand and present the reading report they have been working on, consequently the learning outcome of this subject is not going well and the students' learning result is still low.

The result of Student Needs Questionnaires on Textbooks shows that students of Economics education department, STKIP PGRI Sumatera Barat 100\% agreed on assessment of economics learning outcome textbook used for lectures. Students $100 \%$ agree if in the presentation assessment of economic learning outcomes textbook used learning methods. Students 95\% agree if explained the meaning Assesment of Economic Learning Outcomein textbooks. Students $98 \%$ agree the material in this course is delivered briefly and clearly. $90 \%$ of students agree to use textbooks equipped with materials and evaluation in accordance with the syllabus.

\section{Stage of Design:-}

Stage of design is the initial design stage for preparing the learning devices on the assessment of economic learning outcomes using CTL approach. At this stage is designed various learning devices, namely Semester Learning Plan with CTL approach, syllabus with CTL approach, Lecture Unit with CTL approach, and textbook with CTL approach. The textbook draft is designed based on the Semester Learning Plan, and Lecturer Unit. In the draft of the textbook, there are the cover, table of contents, learning activity materials, exercises, tests/evaluations, and bibliography. Once everything is designed then proceed with the development of learning devices.

\section{Stage of Develop:-}

Stage of development is the development stage of a product that has been validated by the validator. Validation results will be revised to the developed product.

\section{Semester Learning Plan Validation Results:-}

The validity of the semester learning plan is reviewed on several indicators, namely description of content eligibility, aspects of language eligibility, aspects of presentation eligibility, and aspects of graffiti eligibility. The validation results show that the Semester Learning Plan has been developed belongs to a very valid criterion with an average validity of 3.77 (Table 2 ).

Table 2:-Results of validity of lesson plan semester

\begin{tabular}{|c|l|c|c|}
\hline NO & \multicolumn{1}{|c|}{ Indicator } & Average & Criteria \\
\hline 1 & Description of eligibility of content & 4.22 & Very valid \\
\hline 2 & Aspects of language eligibility & 3.50 & Very valid \\
\hline 3 & Aspect of presentation eligibility & 3.87 & Very valid \\
\hline 4 & Aspect of graffiti eligibility & 3.50 & Very valid \\
\hline & Total & 3.77 & Very valid \\
\hline
\end{tabular}

\section{Lecture Unit Validation Results:-}

The validation result of the lecture unit is at very valid criteria with the average validity of 3.26. (Table 3). The validity of the lecture unit is done on several indicators, which are the description of content eligibility, aspects of language eligibility, aspects of presentation eligibility, and aspects of graffiti eligibility. 
Table 3:-Results of validity of lecture unit

\begin{tabular}{|c|l|c|c|}
\hline NO & \multicolumn{1}{|c|}{ Indicator } & Average & Criteria \\
\hline 1 & Description of eligibility of content & 3.56 & Very valid \\
\hline 2 & Aspects of language eligibility & 3.00 & Valid \\
\hline 3 & Aspect of presentation eligibility & 3.50 & Very valid \\
\hline 4 & Aspect of graffiti eligibility & 3.00 & Valid \\
\hline & Total & 3.26 & Very valid \\
\hline
\end{tabular}

Textbook validation result:-

Validation result of textbooksby two validators indicates that textbook belongs to a very valid criterion with an average validity score of 3.35 (Table 4 ).

Table 4:-The results of the textbook validation

\begin{tabular}{|c|l|c|c|}
\hline NO & \multicolumn{1}{|c|}{ Indicator } & Average & Criteria \\
\hline 1 & Description of eligibility of content & 3.47 & Very valid \\
\hline 2 & Aspects of language eligibility & 4.00 & Very valid \\
\hline 3 & Aspect of presentation eligibility & 3.27 & Very valid \\
\hline 4 & Aspect of graffiti eligibility & 3.66 & Very valid \\
\hline & Total & 3.35 & Very valid \\
\hline
\end{tabular}

\section{Discussion:-}

This research is to develop and validate learning devices in the assessment of economic learning outcomes subject. The result of the validator's assessment of the learning devices shows that the learning devices developed belong to very valid criteria. A learning device is categorized as valid if it has a validity value of 90-100\% (Purwanto, 2007). Learning devices in the Assessment of economic learning outcomes subject with CTL approach can improve students' conceptual understanding. CTL approach is an approach involving students' knowledge and experience in daily life (Selvianiresa and Prabawanto, 2017).

The same study by Susilowati et al. (2017) shows that the development of integrated learning devices on creative economic activities in Elementary school is classified as very valid criteria. In contrast to research results obtained Hariani (2015) showed the development of learning devices on subjects Economics in the high school belonging to the valid criteria. Development of Economic Learning devices in Humanistic Based Material of Consumption and Investment The Cooperative Model Two Stay Two Stray belongs to valid criteria (Nugroho et al., 2012).

The development of textbooks is based on a questionnaire of student needs and the results of interviews with other lecturers who teach courses on the assessment of economic learning outcomes. Almost all students agree when in lectures using textbooks using CTL approach. Textbooks using CTL approach can overcome student difficulties, improve student concept understanding, and improve student learning outcomes.

The results of the textbook validity in the Assessment of Economic Learning Outcomes subject pertained to criteria are very valid (Table 5). In the description of the content eligibility of teaching textbooks in the course of assessment of learning outcomes fall into the criterion is very valid. Although the criteria are very valid in terms of material, there is some material that should be revised according to the suggestion of the validator. But the outline of the material contained in the textbook has been referring to the competency standards contained in the planned semester and syllabus learning that has been developed.

The aspect of language eligibility has a very valid criterion with an average value of validity of 4.00. The revision made by the validator is to correct the wording errors in the learning materials and improve the writing of the term used to be easily understood by the students.

Aspect of presentation textbook has very valid criteria with the average validity of 3.27. The benefits of instructional media in the learning process is to attract students' attention so as to foster motivation to learn, learning materials will be more clear meaning that can be better understood by the students and enable students to master the goal of better learning (Rusman, 2012). 
The results of graffiti aspect have been included in the very valid category. Aspects assessed from graffiti include the presentation of fonts and display design.

Validation conducted by two validators who are experts in the field of economic education and Indonesian language and literature education stated that the textbook of the Assessment of Economic Learning Outcomes using CTL approach has been very valid with an average of 3.35 which means the validity of this result can be justified. The same research result has also been done by Wati et al, 2018 where the validation of concept map based module in Evolution course is at very valid criterion that is $92,18 \%$. In contrast to the results of validity testing of student worksheets based on Mastery learning in Genetics subject are on valid criteria with a value of $88 \%$ (Megahati et al., 2016). Likewise with the development of textbooks using the 4-D model toincrease the success of Islamic education learningis on valid criteria (Fajri and Taufiqurrahman, 2017). Based on the results of research that has been obtained textbook assessment of economic learning outcomes by using CTL approach is very valid so that it can be used by students of the economic education department, STKIP PGRI Sumatera Barat.

\section{Conclusion:-}

The resulting learning devices are categorized as highly valid. The assessment of economic learning outcomes textbooks with Contextual Teaching and Learning (CTL) approach can be used in learning at the economic education department, STKIP PGRI Sumatera Barat.

\section{Acknowledgments:-}

The research team would like to thank all those who have supported this research especially the DRPM DIKTI who has funded this research.

\section{References:-}

1. Fajri, K and Taufiqurrahman. (2017). Pengembangan Buku Ajar Menggunakan Model 4D dalam Peningkatan Keberhasilan Pembelajaran Pendidikan Agama Islam. JPII 2(1): 1-15

2. Glynn, S. M, and Winter, L.K. (2004). Contextual Teaching and Learningof Science in Elementary Schools. Journal of Elementary Science Education. 16(2): 51-63.

3. Hamalik, O. (2008). Kurikulum dan Pembelajaran. Jakarta: BumiAksara

2. Hariani. LS. (2015). Merancang Perangkat Pembelajaran Ekonomi SMA Kelas X Materi Masalah Ekonomi dan CaraMengatasinya dengan Pendekatan Sainstifik. Prosiding Semiar Nasional Pendidikan Ekonomi \& Bisnis.

3. Hudson, C.C and Whisler, V. R. (2017). Contextual Teaching and Learning for Practitioners. Systemics, Cybernetics And Informatics Journal. 6(4): 54-59

4. Johnson. (2002). Contextual Teaching and Learning: What It Is and Why It's Here to StayCalifornia: Corwin Press, Inc.

5. Nugroho. 2012. Pengembangan Perangkat Pembelajaran Ekonomi pada Materi Konsumsi dan Investasi Berbasis Humanistik Model Kooperatif Two Stay Two Stray. Innovative Journal of Curriculum and Educational Technology. 1(2):1-7.

6. Megahati, R.R.P, Susanti, D and Yanti, F. (2016). Uji Validitas Lembar Kerja Mahasiswa (LKM) Berbasis Mastery Learning Pada Mata Kuliah Genetika. Unnes Journal of Biology Education. 5(1): 50-54.

7. Purwanto. (2007). Pengembangan Modul. Jakarta.

8. Rusman. (2012). Model-model Pembelajaran. Depok: Raja Grafindo Persada

9. Selvianiresa, D and Prabawanto, S. (2017). Contextual Teaching and Learning Approach ofMathematics in Primary Schools. Journal of Physics: Conf. Series 895.

10. Susilowati, B, Subroto, W.T, and Nasution. (2017). Pengembangan Perangkat PembelajaranTerpadu Berbasis kegiatan Ekonomi Kreatif untuk Siswa Kelas IV SD. Jurnal review Pendidikan Dasar. 3(2):410-414.

11. Trianto. (2010). Model Pembelajaran Terpadu: Konsep, Strategi, dan Implementasi dalam Kurikulum Tingkat Satuan Pendidikan (KTSP). Jakarta: Bumi Aksara.

12. Wati, M, Fitriani, V and Megahati, RRP. 2018. Design and Validity of Module Based onConcept Map In The Course Of Evolusi. International Journal of Advanced and Research. 6(2): 658-661. 